\title{
Knowledge of Vegetables Farmers in the Use of Pesticides
}

\author{
Andi Tenriola Rivai ${ }^{1}$, Abdul Halim, Djafar Amir ${ }^{2}$ \\ Institute of Local Government, Gowa Regency, South Sulawesi, Indonesia
}

\begin{abstract}
This study aims to determine the level of knowledge of vegetables farmers on the use of pesticides, and the frequency of the use of pesticides by farmers to vegetables plant in a planting season. The research was con-ducted in the district Tinggimoncong, Gowa regency, South Sulawesi Province, Indonesia. The study was start from March to June 2015. This study used a survey method. Data were collected through observations, questionnaires and depth interviews with 100 vegetables farmers. Data were analyzed using the quantitative descriptive with cross-tabulation. The results showed that the majority of farmers still low has level of knowledge about the use of pesticides. Therefore, the input use of pesticides is still quite high. The frequency of the use of pesticides in each planting season is still quite high at 15 times to plant cauliflower, 9 times to plant potatoes, and 10 times for the cabbage.
\end{abstract}

Keywords: knowledge of farmers, pesticide, vegetables.

\section{Introduction}

Research on the level of pesticide residues in agricultural and food commodities as well as in the environment, including soil, water and organisms have been carried out [1-5], including efforts to detoxify. Since chemical pesticides or synthetic discovered and used by many farmers.

In Ethiopia, the chemical pesticides used by way of intensive and highly risk to use on human health [6]. In China, the production of pesticides in the past two years has grown to more than 12 times [7]. While data from the use of pesticides in Indonesia is difficult to access, but according to data from the Indonesian National Commission, a registered trademark of pesticides in 1998 only 500. However, in 2003, the number doubled to 1040, and in 1600 the brand in 2006 [8].

In Indonesia, the use of chemical pesticides vegetable growers, is still quite high. The high demand for vegetables provides a logical consequence for farmers to expand planting areas, as well as improved quality. It certainly further encourages the use of pesticides in excess, so that it produces good quality vegetables. In fact, farmers do not hesitate to use pesticides at levels that harm the environment. One potential vegetable producing areas in South Sulawesi are the District Tinggimoncong, Gowa. Farmers in the region to use pesticides to get quality vegetable crops, and pest-free. Therefore, this study was conducted to determine the farmers' knowledge about pesticides and frequency of pesticide use on vegetable crops in the district Tinggimoncong, Gowa.

\section{Research Methods}

This study was conducted from March to June 2015 in the village of Kanreapia and Tonasa Village, District Tinggimoncong, Gowa, South Sulawesi Province, Indonesia. The method used was a survey method and it was conducted from March to June 2015. The village is a vegetable supplier in Gowa and Makassar. While this type of sampling is used in every village is stratified random sampling, by only the production of vegetables, and the types of vegetables are grown (potatoes, cauliflower, and cabbage), with the consideration that society widely uses the vegetables as fresh vegetables (consumption fresh). The collection of data through direct observation, interviews, and questionnaires. Data analysis using quantitative descriptive by using cross tabulation.

\section{Result and Discussions}

\subsection{Knowledge Farmers About Pesticides}

Pesticides are used for improving production of vegetable farmers in the district Tinggimoncong when encountering pests and diseases. Based on the results of in-depth interviews and questionnaires, data about understanding and reason vegetable farmers use pesticides (Table 1).

Table 1 shows that the farmers' knowledge about the intended use of the pesticide is to kill pests/disease (49.20\%), and more than half of the respondents $(52.94 \%)$ know that the function of each pesticide to eradicate the pests/diseases. The main reason farmers use pesticides are quite diverse, but approximately $41.61 \%$ reasonable to follow the advice of extension workers, during the rest because it is only following the advice of fellow farmers $(31.37 \%)$, and there also have a reason to increase crop yields $(27.02 \%)$.

This shows that the farmers' knowledge about the use of pesticides on crops is still low. All respondents chose pesticides as the best alternative in preventing and controlling pests/diseases and weeds on their vegetable crops, because of concerns is a deficiency in production and expect a high yield. Whereas the use of pesticides is not wise will cause negative impacts on the surrounding environment. According to Weaver (1996); Lichtenberg \& Zimmerman (1999); Yuantari et al. (2015); Matthews (2016), some of the results in Illinois, Iowa, Nebraska, and Ohio inform, that farmers who have better knowledge of the environment would be willing to reduce the use of pesticides and insecticides in the area of land. 


\section{International Journal of Science and Research (IJSR) \\ ISSN (Online): 2319-7064}

Index Copernicus Value (2015): 78.96 Impact Factor (2015): 6.391

Table 1: Knowledge and reason vegetable farmers use pesticides

\begin{tabular}{|c|c|c|c|c|}
\hline \multirow[t]{2}{*}{ The farmers' knowledge } & \multicolumn{3}{|c|}{ Number of farmers (\%) } & \multirow{2}{*}{$\begin{array}{c}\text { Average } \\
n=100\end{array}$} \\
\hline & $\begin{array}{c}\text { Cabbage } \\
n=34\end{array}$ & $\begin{array}{c}\text { Cauliflower } \\
\mathrm{n}=32\end{array}$ & $\begin{array}{c}\text { Potato } \\
n=34\end{array}$ & \\
\hline \multicolumn{5}{|l|}{$\begin{array}{l}\text { Knowing about the } \\
\text { intended use of } \\
\text { pesticides: }\end{array}$} \\
\hline $\begin{array}{l}\text { - Prevention of pests / } \\
\text { diseases }\end{array}$ & 44.12 & 28.12 & 11.76 & 28.00 \\
\hline - Kill pests / diseases & 44.12 & 59.38 & 44.12 & 49.20 \\
\hline $\begin{array}{l}\text { - Prevention or kill pests } \\
\text { / diseases }\end{array}$ & 11.76 & 12.50 & 44.12 & 22.79 \\
\hline \multicolumn{5}{|l|}{$\begin{array}{l}\text { Knowing about the } \\
\text { function of pesticides: }\end{array}$} \\
\hline $\begin{array}{l}\text { - Each pesticides to kill } \\
\text { the pests and diseases }\end{array}$ & 44.12 & 50.00 & 64.71 & 52.94 \\
\hline $\begin{array}{l}\text { Each pesticide to kill } \\
\text { more than one kind of } \\
\text { pests and diseases }\end{array}$ & 47.06 & 50.00 & 26.47 & 41.18 \\
\hline $\begin{array}{l}\text { Type pesticides vary, } \\
\text { there are specific to } \\
\text { eradicate the } \\
\text { pest/disease only } \\
\text { certain, and there are } \\
\text { also non-specific }\end{array}$ & 8.82 & 0 & 8.82 & 5.88 \\
\hline \multicolumn{5}{|l|}{ Reason to use pesticide: } \\
\hline $\begin{array}{l}\text { - Following suggestions } \\
\text { extension workers }\end{array}$ & 47.06 & 21.88 & 55.88 & 41.61 \\
\hline $\begin{array}{l}\text { - Following the other } \\
\text { farmers }\end{array}$ & 26.47 & 50.00 & 17.65 & 31.37 \\
\hline $\begin{array}{l}\text { - Increase production of } \\
\text { vegetables }\end{array}$ & 26.47 & 28.13 & 26.47 & 27.02 \\
\hline
\end{tabular}

Therefore, knowledge of farmers in the use of pesticides needs to be improved, such as by providing accurate information about the use of pesticides, and the reason for the choice of pesticides to be used. Results of research Andersson \& D'Souza (2014), reveals that the knowledge of farmers in horticulture can be improved through the delivery of the right information, intensive, and comes from a trustworthy source of information.

\subsection{Frequency of Pesticides' Use}

Pesticides are used by farmers every season, with the number and frequency tends to increase. Pesticides are provided by spraying on crops and farming land repeatedly until they are sure that the vegetable plants are free from pests and diseases that can be harmful. Giving pesticides by farmers in each planting to harvest is presented in Table 2 .

Table 2: The average frequency of pesticides on vegetable crops

\begin{tabular}{|l|c|c|c|}
\hline \multirow{3}{*}{ Vegetable } & \multicolumn{2}{|c|}{$\begin{array}{c}\text { Number of pesticide } \\
\text { applications (times) }\end{array}$} & \multirow{2}{*}{$\begin{array}{c}\text { average per } \\
\text { season }\end{array}$} \\
\cline { 2 - 3 } & Rainy season & Dry season & \\
\hline Cauliflower & 12 & 18 & 15 \\
\hline Potato & 8 & 10 & 9 \\
\hline Cabbage & 9 & 11 & 10 \\
\hline
\end{tabular}

Table 2, explained that the application of pesticides on vegetable crops provided the farmers in the rainy season less than in the dry season. The number of pesticides on vegetable crops cauliflower (15 times) is much more than the other two kinds of vegetables (cabbage: 10 times, and potatoes: 9 times), both in the dry season and the rainy season. Variations in the frequency of pesticide application in the field, based on the level of pests and diseases in the vegetable crop, and all the farmers recognize that pests and diseases in the dry season are much more than in the rainy season.

Pesticide repeatedly, actually tends to make it less pesticide efficacy to counteract or eradicate pests and diseases in the vegetable crops $[8,10,14]$. If the pesticide is done at a lower dose than recommended doses, it makes pest/disease that attacks will be more resistant to pesticides [15]. The use of synthetic pesticides in the agricultural system increased rapidly, while the Indonesian farmer awareness about the dangers of pesticides is still low. This is evident from the number of farmers using protective eyewear is only about $3.8 \%$, and the farmers who use boots to protect his feet around $1.8 \%$ [12]. This is a challenge to the use of pesticides in the future.

\section{Conclusion}

In general, farmers' knowledge about the use of pesticides is still low, and the frequency of use of pesticides in each planting season is still quite high at around 9-15 times spraying.

\section{References}

[1] Matthews G. Pesticide Application Methods. Wiley, 2008.

[2] Pimentel D, McLaughlin L, Zepp A, et al. Environmental and economic effects of reducing pesticide use. Bioscience 1991; 41: 402-409.

[3] Sekiyama M, Shimmura T, Nakazaki M, et al. Organophosphorus Pesticide Exposure of School Children in Agricultural Villages in Indonesia. J Preg Child Heal 2015; 2: 2.

[4] Isworo S, Purwanto I, Sabdono A. Impact of pesticide use on organophosphorus and organochlorine concentration in water and sediment of Rawa Pening lake, Indonesia. Res J Environ Sci 2015; 9: 233.

[5] Yanggen D, Cole D, Crissman C, et al. Human health, environmental, and economic effects of pesticide use in potato production in Ecuador. Centro Internacional de la Papa (CIP), 2016.

[6] Ecobichon DJ. Pesticide use in developing countries. Toxicology 2001; 160: 27-33.

[7] Liu EM, Huang J. Risk preferences and pesticide use by cotton farmers in China. J Dev Econ 2013; 103: 202-215.

[8] Sugiarman S, Nurmalina R, Kirbrandoko K. Analysis the impact of product quality and customer service on satisfaction and loyalty of pest control operators in PT Bayer Indonesia. Widyariset 2015; 18: 1-12.

[9] Weaver RD. Prosocial behavior: private contributions to agriculture's impact on the environment. Land Econ 1996; 231-247.

[10] Lichtenberg E, Zimmerman R. Information and

\section{Volume 6 Issue 7, July 2017}


farmers' attitudes about pesticides, water quality, and related environmental effects. Agric Ecosyst Environ 1999; 73: 227-236.

[11] Matthews G. Pesticides: Health, Safety and the Environment. Wiley, 2016.

[12] Yuantari MGC, Van Gestel CAM, Van Straalen NM, et al. Knowledge, attitude, and practice of Indonesian farmers regarding the use of personal protective equipment against pesticide exposure. Environ Monit Assess 2015; 187: 142.

[13] Andersson JA, D'Souza S. From adoption claims to understanding farmers and contexts: A literature review of Conservation Agriculture (CA) adoption among smallholder farmers in southern Africa. Agric Ecosyst Environ 2014; 187: 116-132.

[14] Vemuri SB, Rao CS, Darsi R, et al. Methods for removal of pesticide residues in tomato. Food Sci Technol 2014; 2: 64-68.

[15] Snelder DJ, Masipiqueña MD, De Snoo GR. Risk assessment of pesticide usage by smallholder farmers in the Cagayan Valley (Philippines). Crop Prot 2008; 27: 747-762.

[16] A. Bonnaccorsi, "On the Relationship between Firm Size and Export Intensity," Journal of International Business Studies, XXIII (4), pp. 605-635, 1992. (journal style)

[17] R. Caves, Multinational Enterprise and Economic Analysis, Cambridge University Press, Cambridge, 1982. (book style)

[18] M. Clerc, "The Swarm and the Queen: Towards a Deterministic and Adaptive Particle Swarm Optimization," In Proceedings of the IEEE Congress on Evolutionary Computation (CEC), pp. 1951-1957, 1999. (conference style)

[19] H.H. Crokell, "Specialization and International Competitiveness," in Managing the Multinational Subsidiary, H. Etemad and L. S, Sulude (eds.), CroomHelm, London, 1986. (book chapter style)

[20] K. Deb, S. Agrawal, A. Pratab, T. Meyarivan, “A Fast Elitist Non-dominated Sorting Genetic Algorithms for Multiobjective Optimization: NSGA II," KanGAL report 200001, Indian Institute of Technology, Kanpur, India, 2000. (technical report style)

[21] J. Geralds, "Sega Ends Production of Dreamcast," vnunet.com, para. 2, Jan. 31, 2001. [Online]. Available: http://nl1.vnunet.com/news/1116995. [Accessed: Sept. 12, 2004]. (General Internet site) 